\title{
NCAA Graduation Rates: A Quarter-Century of Re-branding Academic Success
}

\author{
Richard M. Southall \\ University of South Carolina
}

In the opening paragraph of its recently filed appeal of O'Bannon v. NCAA (August 8, 2014), the National Collegiate Athletic Association (NCAA) clearly positions college sport as inextricably tied to higher education:

College sports have a long and cherished history. They contribute to the overall college experience; they play a lasting role for alumni; they attract millions of fans and, at times, large television audiences; and, most significantly, each year they help thousands of people pursue a college education (O'Bannon $v$. $N C A A$, November 14, 2014, p. 2).

Asserting " $[\mathrm{t}]$ he goal of the NCAA is to integrate athletics with academics" (O'Bannon v. NCAA, November 14, 2014, p. 26), NCAA chief legal officer Donald Remy cautioned the U.S. Court of Appeals for the Ninth Circuit to not allow "the plaintiffs and the district court to untether college athletics from the academic experience" (Solomon, 2014, para. 19)

In their brief, the NCAA claimed college athletes are just like any other college students, fully integrated into the academic community and enjoying greater academic success than regular students:

Integrating student-athletes into the academic community improves their educational experience. Full participation in that experience-not just meeting academic requirements, but also studying, interacting with faculty and diverse classmates, and receiving academic support such as tutoring and mentoring-generally leads student-athletes, especially those from disadvantaged backgrounds, to reap more from their education, including enjoying higher graduation rates and better job prospects (O'Bannon v. NCAA, November 14, 2014, p. 11).

In support of this claim, the NCAA has characterized college athletes' academic success as "nothing short of remarkable...with a record percentage of

Southall is the Director, College Sport Research Institute, Department of Sport and Entertainment Management, University of South Carolina, Columbia, SC. Address author correspondence to Richard Southall at southall@hrsm.sc.edu. 
student-athletes achiev[ing] graduation, the ultimate goal of entering college" (Hosick, 2014, para. 3).

\section{The NCAA Brand}

In addition to being an institution comprised of the association (e.g., member institutions, conferences, governance structure and affiliated entities), membership (e.g., colleges and universities), and the national office (National Collegiate Athletic Association [NCAA], 2004, p. 2), the NCAA is also a brand. One of the NCAA's brand attributes is "Student-athlete success on the field, in the classroom and in life" (see ncaa.org public homepage). Athletes' academic success is specifically highlighted, not only on the public homepage, but also throughout the website. Under the pull-down menu heading "What We Do" the first heading is "academics" and "academic success" is prominently highlighted on subsequent links.

From its inception the NCAA brand-like any institutional brand-has faced external threats, such as physical injuries or deaths of athletes, gambling scandals, Congressional inquiries, and "...the dreaded notion that NCAA athletes could be identified as employees by state industrial commissions and the courts" (Byers \& Hammer, 1995, p. 69). Notably, throughout its history the NCAA has also faced a variety of legal challenges (e.g., NCAA v. Board of Regents, 1984; NCAA v. Tarkanian, 1988; Law v. NCAA, 1998; Bloom v. NCAA, 2004). Currently, three legal actions (O'Bannon v. NCAA, 2009, 2014; Jenkins v. NCAA, 2014; and Northwestern and CAPA, 2014), which have been simultaneously praised and condemned as signaling, "the end of college sports as we know it!" embody the ongoing debate as to whether the NCAA college-sport brand is compatible with the stated academic mission of colleges and universities.

What has been lost amid the dissonance of college-sport critics and defenders is the NCAA national office's "focused, centralized leadership" (NCAA, 2010a, para. 1) in advancing the NCAA brand. An integral part of this brand advancement has been a quarter-century-long strategy of rebranding college athletes' academic success. In response to what Greyser (2009) refers to as a "corporate/organizational brand crisis" (p. 590), the NCAA — on an institutional level-has focused on two primary branding/rebranding elements: “...(a) a shared understanding of how individual initiatives should both reflect and connect to the brand, and (b) the discipline to stay on message and on brand" (NCAA, 2010a, para. 1). This academic-success rebranding initiative, is consistent with other rebranding campaigns in which the NCAA created, disseminated and imbedded rebranded concepts, including: "studentathlete" and "Collegiate Model of Athletics" (Byers \& Hammer, 1995, Sack \& Staurowsky, 1998, Southall \& Staurowsky, 2013). Rebranding theory provides a context from which to view twenty-five years of NCAA management and communication decisions in rebranding academic success and yields insight into the association's legal strategies in response to the external threats of O'Bannon, Jenkins and NLRB.

\section{Rebranding Framework}

According to the NCAA, its institutional brand ${ }^{1 ~ " . . . ~ i s ~ a ~ c o l l e c t i o n ~ o f ~ t h e ~ A s s o c i a-~}$ tion's messages, visual presentation, decisions, actions, behaviors, relationships and 
experiences" (NCAA, 2010a, para. 2). Branding nuances include such concepts as "...living the brand, the role of experiences and internal branding" (Merrilees \& Miller, 2008, p. 537). Corporate, organizational or institutional branding involves utilizing traditional marketing communication and planning frameworks to transmit a brand to identified publics (Olins, 1978; Gregory, 1991, Dowling, 1994). In the process of institutional branding, an institution's logics (Southall, Nagel, Amis, \& Southall, 2008) figure strongly and explicitly in the developed brand (Hatch $\&$ Schultz, 2003). Gapp and Merrilees (2006) note such structures are critical to brands, since they are part of each brand's essence.

Rebranding is distinct from branding, which is the "...initial coherent articulation of the corporate brand and can occur at any time (Merrilees \& Miller, 2008, p. 538). Re-branding is the dislocation and reformulation of a brand, resulting in a new brand articulation. A change in the vision associated with a brand often requires (or results from) a change in the management process. Just as initial institutional branding requires getting individuals and institutional units to adhere to institutional logic(s) and ceremonial facades (Southall et al., 2008), re-branding necessitates moving the institution from one mindset or logic(s) to another.

Similar to corporate or organizational rebranding, rebranding on an institutional level occurs in response to identified issues, threats or challenges. The first steps in the rebranding process are focusing on identifying the extent to which the brand needs to be changed, justifying the brand revision to relevant stakeholders, recognizing and anticipating potential internal resistance to such change, developing a well-structured change management program that aligns with an institution's core values and alerting all institutional members to the forthcoming rebranding. In addition to satisfying existing stakeholders and publics, any proposed rebranding must also meet the needs of new market segments. Utilizing internal and external communication platforms, all institutional members must be invested; the rebrand must be consistent with institutional logics.

Most often, if the crisis is not severe, institutions seek to implement a rebranding campaign strategy methodically, integrating rebranding elements through mass and nonmass media platforms. In larger organizational or institutional settings, a branding and communication group that may include the following staff units often coordinates a rebranding process: Brand Strategies and Events (BSE), New Media Strategies and Content Development (NMSCD), and Public and Media Relations (PMR) (NCAA, 2010b). A BSE unit “...provides full-service integrated communications to advance an [institution's] mission" (NCAA, 2010b, para. 5). NMSCD develops an institution's online strategy. PMR “...implements and manages an issues management communication model” (NCAA, 2010b, para. 7). This model includes "...proactive, reactive and crisis-response initiatives and strategies" (NCAA, 2010b, para. 7) that are tailored to identified issues.

Utilizing various communication platforms, an institution can strategically target audiences or publics and aggressively advocate for its brand (NCAA, 2010b). While advertising or public service announcements may be used, effective public relations has a comparative advantage in changing attitudes. Social campaigns can be coordinated through a branding group, which generates content through which the rebrand can be effectively communicated to relevant stakeholders (Southall \& Staurowsky, 2014). According to Merrilees and Miller (2008), regardless of whether the rebranding is minor, intermediate or complete, successful rebranding 
involves conceptualizing a group of core values, vision, mission, and goals and communicating these to relevant publics.

Rebranding may be conceptualized as occurring along a continuum. The level of rebranding may be minor, intermediate or complete (Ahonen, 2008; Daly \& Moloney, 2004). Minor rebranding involves just an aesthetics change, what might be considered a minor facelift. Ahonen (2008) describes intermediate rebranding as more involved, including elements of “...repositioning, and use of marketing tactics, especially communication...techniques to favorably reposition an existing brand" (p. 32). In this type of rebranding, there is still an association with the previous brand. However, in a complete rebrand any ties to the previous brand are intentionally discarded and no attempt is made to retain any association with the previous brand. Consistent with this framework, Stuart and Muzellec (2004) conceptualized rebranding occurring within a range of evolutionary (e.g., new slogan or logo only) to revolutionary change that incorporates elements of name, logo and slogan rebranding simultaneously.

Some suggest the rebranding process occurs in identified phases (Ahonen, 2008; Greyser, 2009). While the phases have been variously titled, most models have similar attributes. For our purposes, the following phases will be identified (see Figure 1): Phase 1-Triggers and Brand Revision, Phase 2-Rebranding Strategy Implementation, and Phase 3-Stakeholder Buy-in and Outcomes.

The first phase: "trigger(s) and re-vision" is when a brand becomes embroiled in a reputational crisis (or series of crises), seeks to make sense of the predicament in which it finds itself, and determines an appropriate response (Greyser, 2009). The trigger(s) may be sudden (e.g., tainted Tylenol capsules) or longitudinal, festering over a long period of time (e.g., FIFA World Cup bribery scandal). The crisis may result from media attention or advocacy group criticism, governmental scrutiny, disaffected consumer/fan complaints, or general public dissatisfaction. In this phase, the institution's immediate response can be either proactive or reactive. The reputational crisis may be life-threatening to the institution and its brand when the situation affects the essence of the brand (Greyser, 2009; Merrilees \& Miller, 2008).

In response to a crisis an institution will likely seek to react as quickly as possible, but will simultaneously analyze antecedents or driving forces behind the crisis and seek to develop a proactive response (Ahonen, 2008). This initiative often involves conducting a situational analysis to identify the brand's essential elements and meaning (e.g., strengths and weaknesses), develop a more complete understanding of the crisis situation, and initiate an internal brand revisioning discussion. Throughout this phase the institution still seeks to maintain continuity with past brand meanings. There may be a call to return to the institution's beloved roots (e.g., return to a model of true amateurism, recapture the American auto industry's
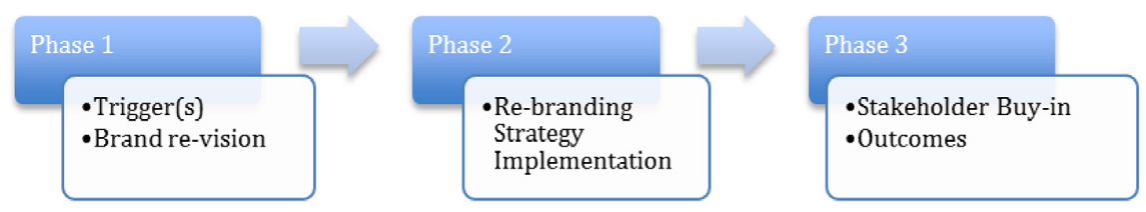

Figure 1 - Phases of Rebranding. 
glory days). As revisioning proceeds, an institution will make a series of rebranding decisions, including whether to reposition, rename, restructure, or redesign.

Having decided on a course-of-action, the institution's leadership will seek to implement a chosen strategy or series of strategies. Successful implementation involves insuring internal brand understanding and executing selected rebranding activities. While these initial steps are being undertaken, an institution may choose to also maintain continuity with past brand meanings while simultaneously obtaining stakeholder buy-in and methodically implementing rebranding campaign (Ahonen, 2008).

Transitioning to the final phase involves gaining stakeholder buy-in and developing specific reputational management tactics consistent with reimagined "core" values, vision, mission, and goals (NCAA, 2010b; Southall \& Staurowsky, 2014). Any rebranding plan must insure successful implementation of chosen internal and external marketing mixes. Coordination is crucial and is most often the responsibility of a branding and communication group or functional unit.

Having delineated the rebranding process, the following section summarizes a specific historic campaign, in which the NCAA responded to an academic reputational crisis by rebranding academic success. Institutional memos, briefing documents, research presentations and commissioned reports chronicle how-in response to negative publicity about college athletes' poor academic performance (i.e., extremely low graduation rates in NCAA Division-I football and men's basketball) the NCAA has engaged in a twenty-five year rebranding campaign designed to create, disseminate and imbed a new definition of academic success. These data support the conclusion that the Academic Progress Program (APP)—specifically the Graduation Success Rate (GSR) - has been part of a coordinated rebranding strategy designed to protect the collegiate model of athletics by advocating "...for the positive aspects of intercollegiate athletics as they relate to higher education" (NCAA, 2010b, para. 1) to several external publics, including Congress, the media, corporate partners, college sport fans, recruits and their parents, and the general population.

\section{A Quarter-Century of Rebranding Academic Success}

\section{Phase One: Triggers and Brand Revision}

While NCAA D-I college football and men's basketball players have historically graduated at significantly lower rates than the general student body (NCAA, 1991), it was not until the mid-1980s that this phenomenon among big-time college football and men's basketball players was a well-chronicled issue (Byers \& Hammer, 1995; Hall v. University of Minnesota, 1982; and Ross v Creighton University, 1992). Strikingly, Nyad (1989) reported 76-92\% of professional football and men's basketball players lacked college degrees. In the late 1980s former NCAA and Olympic basketball players, believing prospective college athletes and their parents had a right to information about their likelihood of graduating, began lobbying members of Congress to force U.S. colleges and universities to publish college athletes' graduation rates (Selingo, 2012). Public scrutiny intensified when several high profile athletes, including former Oklahoma State University (OSU) defensive end Dexter Manley, revealed before Congress that they were functionally illiterate (Jacobson, 1992). Manley testified that despite being enrolled and playing football at OSU for four years, he had not learned to read until well after he had left college 
(Jacobson, 1992). Subsequently, the 1990 Student Right-to-Know and Campus Security Act (SRTKA) included a Department of Education (DOE) administered program, which required colleges and universities to collect and disseminate student graduation rates (i.e., Federal Graduation Rate [FGR]) (See National Center for Educational Statistics website: http://nces.ed.gov/collegenavigator/). After initially voicing concerns over the federal program, the NCAA acquiesced and agreed to make athlete graduation rates public (Selingo, 2012).

In response to the academic crisis, and before the passage of the Student Rightto-Know Act, the NCAA commissioned a series of research projects to "inform our member institutions and others" (NCAA, 1991, p. 1) about college athletes' graduation rates. One project was the NCAA Academic Performance Study (APS), which began in 1985 (NCAA, 1994). One of the first reports, published in 1991, highlighted the five-year graduation rates of a sample of NCAA athletes $(N=3,288)$ who had enrolled as first time in college students in 1984 or 1985 (NCAA, 1991, p. 6) The employed methodology was similar to the one eventually used in the six-year FGR: "The graduation rates for the following tables were calculated by dividing the number of graduates after five years by the number of student-athletes who had entered that institution as freshmen in the initial year of the survey" (NCAA, 1991, p. 6). However, the study also reported an "adjusted graduation rate...calculated by removing all student-athletes who left their institutions in good academic standing from the group of initially entered freshmen" (NCAA, 1991, p. 6).

In this initial report, athletes removed from the initial graduation-rate cohort were referred to as "eligible dropouts" (NCAA, 1991, p. 10). As can be seen in Table 1 , this adjustment removed approximately $33 \%$ of athletes from the sample and resulted in an overall adjusted graduation rate of $68.4 \%$ - an improvement of $22.7 \%$. For male revenue sport athletes, the adjustment, the precursor of the GSR, resulted in a $20.4 \%$ jump, from $42.1 \%$ to $62.5 \%$. In subsequent peer-reviewed articles (i.e., McArdle \& Hamagami, 1994) as well as NCAA reports (see http:/www.ncaa.org/ about/resources/research/academic-initial-eligibility-research), there was no mention of eligible dropouts or an adjusted graduation rate. It seemed as if the "eligible dropout" effect had been forgotten, just another statistical analysis in yet another report.

\section{Phase Two: Rebranding Strategy Implementation}

However, when the NCAA “. . .launched a major academic reform program in 2003" (LaForge \& Hodge, 2011, p. 219), the eligible-dropout adjustment reappeared as the cornerstone of the Graduation Success Rate. The adjustment was necessitated because, "The federally mandated rate is an inaccurate graduation measure" (Brand, 2004, para. 53). In virtually every NCAA document, communiqué, or press release since 2003, the GSR has been identified as an improved and more accurate metric that was developed at the request of NCAA members, particularly presidents and chancellors. This narrative was initially established in both the 2003 and 2004 NCAA state of the association addresses, when NCAA president Myles Brand highlighted the GSR as evidence of the newly-instituted reform agenda's success (Brand, 2003, 2004).

Subsequent to the introduction of the GSR, its positioning as a more accurate measure of academic success has become ubiquitous, being imbedded in almost every press release and news story on the NCAA.org website, in the mainstream media and on university athletic-department websites. In addition, the FGR is 


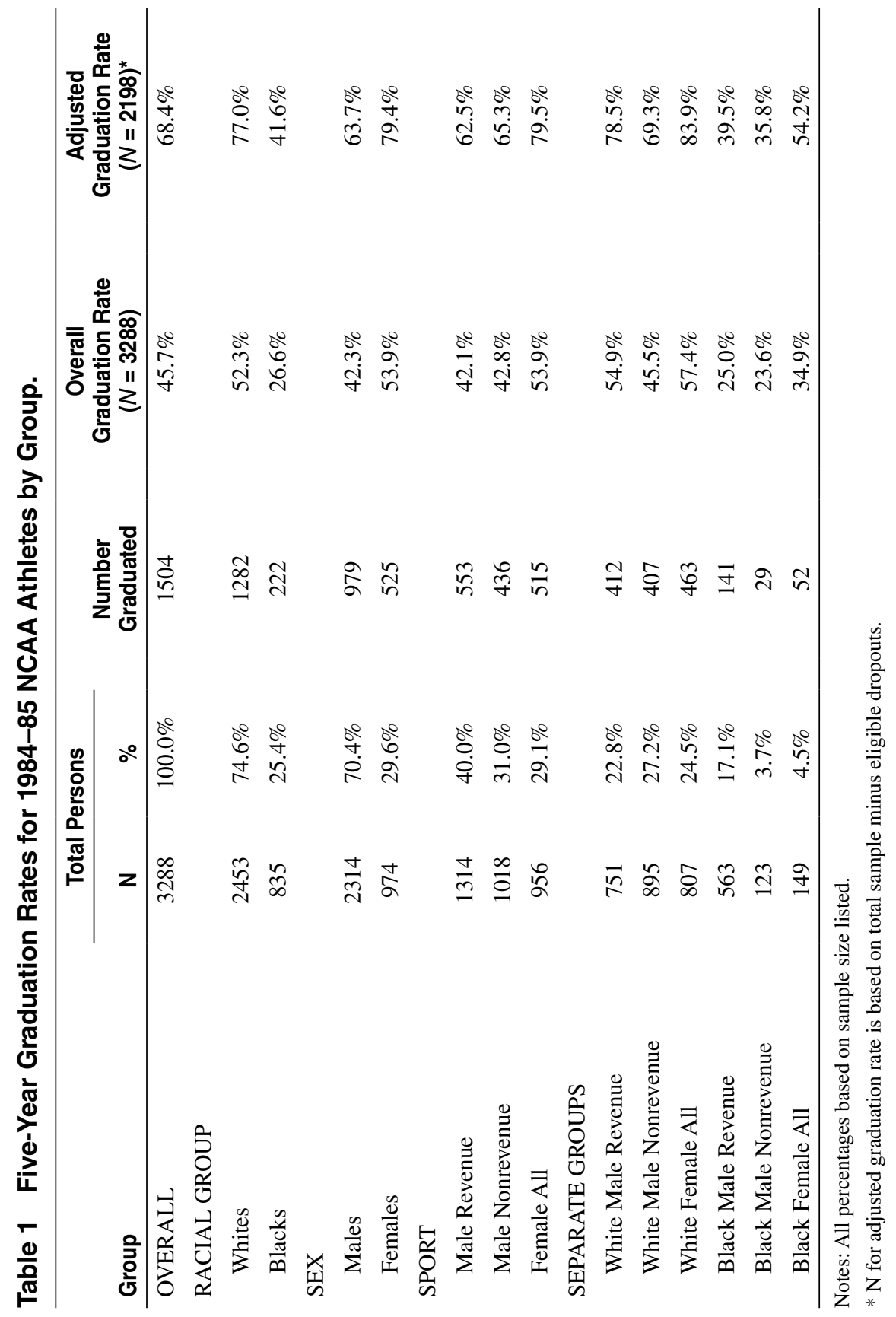


consistently described as divorced from reality, understating and/or misstating graduation results: "The NCAA also devised a new metric for measuring graduation in an effort to amend the shortcomings of the federally mandated methodology" (Brown, 2014, para. 11).

With the most recent release of NCAA graduation rates, the degree to which the NCAA's rebranding strategy has been implemented is readily apparent. In the following excerpts from press releases posted on an athletic department or conference websites there is one consistent message: "The GSR is a more accurate and better measure that proves athletes are achieving academic success."

\section{University of South Florida}

The NCAA developed the Division I Graduation Success Rate in response to college and university presidents who wanted graduation data that more accurately reflect the mobility among all college students today.

The GSR is the NCAA's more inclusive calculation of academic success among scholarship student-athletes. The NCAA rate is more accurate than the federally mandated methodology...

http://www.gousfbulls.com/View Article.dbml?DB_OEM_ID= 7700\&ATCLID=209739013

\section{University of Notre Dame}

The GSR was created to more accurately reflect actual graduation rates by including transfer data in the calculation. College and university presidents asked the NCAA to develop a new methodology that takes into account the mobility among students in today's higher education environment. Research indicates that approximately 60 percent of all new bachelor's degree recipients are attending more than one undergraduate institution during their collegiate careers.

http://www.und.com/genrel/102914aac.html

\section{University of Oregon}

Unlike the federal rate, which tracks only those who enrolled as freshmen and counts all students who leave school or transfer to another college against the overall rate, regardless of whether or not they graduate from another University, the GSR takes two- and four-year transfer student graduation rates into account. Additionally, a student-athlete who leaves an institution in good academic standing does not count against a school's GSR.

http://www.goducks.com/View Article.dbml?DB_OEM_ID= 500\&ATCLID=209737235

\section{Atlantic Coast Conference}

The Graduation Success Rate was developed by the NCAA as part of its academic reform initiative as a better measure of student-athlete academic success... 
The federal graduation rate, which is less accurate than GSR because it counts transfer students as academic failures, is the only rate that allows comparison between the general student body at a school and its student-athletes.

http://www.theacc.com/\#!/news-detail/acc-teams-continue-to-set-highgraduation-success-rate-2014-10-28

\section{Louisiana State University}

The NCAA developed the Graduation Success Rate to more accurately assess the academic success of student-athletes.

http://www.lsusports.net/ViewArticle.dbml?ATCLID=209746592

\section{University of Alabama-Tuscaloosa}

The NCAA GSR and the Academic Success Rate (ASR) were developed in response to college and university presidents who wanted graduation data that more accurately reflected the mobility among college students today. Both rates improve on the federally mandated graduation rate by including students who were omitted from the federal calculation.

http://www.rolltide.com/genrel/102814aaa.html

\section{Phase Three: Stakeholder Buy-in and Outcomes}

While the NCAA has "... established itself as a strong brand, with its own unique attributes" (NCAA, 2010a, para. 4), over the past twenty-five years the NCAA has been increasingly challenged to "...provide an alternative to the doggerel of cynics" (NCAA, 2010b, para. 4) and protect its brand-the Collegiate Model of Athletics in both the court of public opinion and U.S. federal court. The collegiate model is ".... a term of art... created by Myles Brand [late NCAA president] as a surrogate for - but not a replacement for - the concept of amateurism to the degree it was too frequently used as a descriptor for intercollegiate athletics" (NCAA, 2010c, para. 1).

The importance the NCAA places on this quarter-century academic success rebranding strategy is reflected in its status as the first outcome-oriented goal (i.e., "Goals are outcome-oriented statements that represent what will constitute the organization's future successes" [NCAA, 2004, p. 6].) in the NCAA's 2004 Strategic Plan: "Student-athletes will be better educated and prepared for increased lifelong achievement and success" (NCAA, 2004, p. 6). Consistent with fundamental strategic-management principles the NCAA strategic plan also outlined several objectives, including: "1.2 Increase the number of student-athletes who succeed academically" (NCAA, 2004, p. 6).

Not surprisingly, NCAA national office staff members consistently adhere to this developed rebranding strategy in communicating with internal stakeholders (e.g., university presidents, faculty athletic representatives). In addition, on July 8, 2014-amid increased Congressional scrutiny and on the heels of a significant legal challenge to its collegiate model (i.e., O'Bannon v. NCAA)—NCAA president Mark Emmert used this rebranded definition of academic success throughout his testimony before the U.S. Senate Committee on Commerce, Science \& Transportation. Coming at a time when the NCAA faced "...pressure from multiple fronts to reform how athletes are treated and compensated" (The Associated Press, 2014, 
para. 7), the committee's goal was to gain a better understanding of "...how the NCAA is integrating athletics with academics and to determine if student-athletes are being exploited in the process" (McGuire, 2014, para. 1). Leading up to the hearing, several committee members had expressed concern about the NCAA's policies, oversight of member institutions, and potential exploitation of athletes.

In this challenging environment (Herndon, 2014) Emmert focused on the association's “...first and foremost [mission]... to promote student-athlete success in the classroom" (NCAA, 2014a, para. 2). He also highlighted "a core truth of intercollegiate athletics" (NCAA, 2014a, para. 5):

For the vast majority of those who participate in NCAA sports - more than 460,000 young men and women each year at 1,084 institutions across three divisions and in 23 different sports - the experience is exactly what it is intended to be: a meaningful extension of the educational process that provides the opportunity for students to compete fairly against other students, in an educational environment (NCAA, 2014a, para. 5).

Highlighting this success, he noted “...participants in athletics are more likely to go to college, to stay and graduate from college, to secure a good job after college, and earn more money within a few years after college and for a lifetime" (NCAA, 2014a, para. 6).

However, while contending most Americans view college sport in a positive light, he acknowledged concerns about issues and challenges associated with the experiences of NCAA Division-I Football Bowl Subdivision [FBS] football and men's basketball players at 123 well-known institutions in the larger conferences, while noting these athletes "...represent only 3.5 percent of all NCAA studentathletes" (NCAA, 2014a, para. 9). Subsequently, Emmert touched upon a host of issues and concerns and mentioned three key points that he felt often go unnoticed or unmentioned. Two of the points included: (a) NCAA sports provide access to higher education for a significant number of first-generation students, including “... many whose financial situation would have otherwise prevented them from attending college" (NCAA, 2014a, para. 13). (b) The NCAA has substantially increased support of college athletes' academic success (NCAA, 2014a).

Contending the NCAA had made tremendous progress in addressing historic academic concerns, he offered several success stories, including annual spending of $\$ 2.1$ billion on athletic scholarships, increased initial eligibility requirements, mandatory progress toward degree requirements, as well as stringent Academic Progress Rates (APRs) and "record" Graduation Success Rates (GSRs). Specifically, focusing on the most visible sports of FBS football and men's basketball, he referred to NCAA data that shows FBS football players "graduate" at a rate of $71 \%$, while Division I men's basketball players are graduating at a rate of $73 \%$-a 17 percentage-point increase since 1995 (NCAA, 2014a).

\section{Conclusion}

Clearly Emmert's testimony-archived on the NCAA media center under the headline: "NCAA president's testimony on value of college model"-was meant to offer evidence the association acts in a manner consistent with its first core value "... a belief and commitment to: The collegiate model of athletics in which 
students participate as an avocation, balancing their academic, social and athletic experiences" (NCAA, n.d., emphasis in original).

However, throughout his remarks, which were an extension of the last 25 years of NCAA rebranding, Dr. Emmert conveniently failed to mention or address the following four points:

1. Neither the FGR, nor the GSR is perfect or inherently a more accurate metric; they use different sampling and statistical analyses to examine different cohorts. In short, they are different graduation rates.

2. The GSR consistently returns a "success" rate 12-25\% higher than the FGR. As far back as 1989 (NCAA, 1991), the NCAA knew that removing 1/4-1/3 of "eligible dropouts" from a "graduation rate" sample would result in a markedly higher "success" rate.

3. A comparison of published FGRs of NCAA athletes and the general student population includes a significant number of part-time students at many schools. This is problematic because NCAA athletes must be "full-time" students making progress toward a degree. Consequently, it makes sense to compare full-time college athletes with other full-time students. Without adjusting for the possible downward "part-timer bias" in the student-body rate, any comparison is likely distorted-or somewhat skewed. Because part-time students take longer to graduate, general student-body FGRs may be significantly lower, making the relative rate of college athletes at many schools and conferences appear more favorable.

4. Finally, since there is no comparable national-level GSR for the general student body, GSR and FGR data should not be reported simultaneously in press releases or news accounts. The NCAA's consistent comingling of FGRstudent and GSR-athlete in press releases or dataset tables invites inappropriate comparisons and fosters confusion.

Not surprisingly, given ongoing legal challenges to its collegiate (or "college") model, the NCAA national office has systematically developed and implemented a rebranded definition of academic success that seeks to convince a skeptical public that "the business of college sports is not a necessary evil, [but] a proper part of the overall enterprise" (Brand, 2006, p. 8). As a result creating, refining, imbedding a rebranded definition of academic success, and documenting the association's unprecedented academic success has become a primary focus of the office of the NCAA president. This rebranding strategy, consistent with Southall and Staurowsky's (2013) analysis of NCAA institutional propaganda, has sought to blunt criticisms of big-time college sport by pointing to record graduation rates as evidence college athletes are provided an opportunity for a world-class education. While such systematic and sustained rebranding is not inherently unethical, its use to silence criticism and obscure critical analysis of the NCAA's business model is problematic, especially in an educational setting.

The NCAA's rebranding strategy has succeeded in obscuring its institutional hegemony (Gramsci, 1971; Southall \& Staurowsky, 2013) and allowed it to portray itself as nothing more than an educational association. Consistent with Adamson's (1980) analysis, the NCAA has successfully wielded its rebranded "success" rate as a linguistic and philosophical "armor of coercion" (Adamson, 1980) to deliberately form, control, and alter the attitudes of those within the institutional field of college sport. 
Clearly the NCAA national office has been in the forefront of advancing the NCAA brand. Utilizing the APR and GSR as evidence, for the past quarter-century the NCAA has shown remarkable discipline in staying on message and on brand in successfully rebranding college athletes' academic success. Following a game plan first established in the 1950s, the association seems to be hoping a rebranded definition of academic success will offer camouflage for its profit-seeking tendencies. Within an institutional field in which a new College Football Playoff is expected to yield a $\$ 500$ million return on two end-of-season semifinal games leading to a "national" championship extravaganza (Schroeder, 2012) and the NCAA grosses nearly $\$ 800$ million per year as a result of its multibillion dollar March Madness contract (Clarke, 2013), it is increasingly clear the NCAA national office's very existence relies on how successful "the steady drumbeat... [of the NCAA's] aggressive public and media relations agenda" (NCAA, 2010c, para. 3-4) is at convincing Congress, the courts, the media, college-sport fans and the general public that academic success, not maximizing revenues (Brand, 2006), is the association's real "core" value.

\section{Note}

1. The focus in this essay is on the NCAA as an institution (Southall et al., 2008). Consequently, while some of the literature utilizes analyses of branding/rebranding on corporate or organizational levels, these theoretical constructs are applicable to institutional branding/rebranding. Such usage is consistent with the literature, in which similar properties are applied to corporate, organizational, retail, service, and institutional brands (Berry, 2000; Birtwistle \& Freathy, 1998).

\section{References}

Adamson, W. L. (1980) Hegemony and revolution: A study of Antonio Gramsci's political and cultural theory. Berkeley: University of California Press.

Ahonen, M. (2008). Corporate re-branding process: A preliminary theoretical framework. In W. J. L Elving (Ed.), Proceedings Conference on Corporate Communication 2008 (pp. 31-38).

Associated Press. (2014, July 9). NCAA President Mark Emmert calls for 'scholarships for life', other reforms. Retrieved from http://www.ncaa.com/news/ncaa/article/2014-07-09/ ncaa-president-mark-emmert-calls-scholarships-life-other-reforms

Berry, L. (2000). Cultivating service brand equity. Journal of the Academy of Marketing Science, 28(1), 128-137. doi:10.1177/0092070300281012

Birtwistle, G., \& Freathy, P. (1998). More than just a name above the shop: A comparison of the branding strategies of two UK fashion retailers. International Journal of Retail \& Distribution Management, 26(8), 318-323. doi:10.1108/09590559810231788

Bloom v. National Collegiate Athletic Association, 93 P.3d 621 (Colo. App. 2004).

Brand, M. (2003, January 20). State of the association address. NCAA News. Retrieved from http://fs.ncaa.org/Docs/NCAANewsArchive/2003/Association-wide/state+of+the+ass ociation+address+-+1-20-03.html

Brand, M. (2004, January 19). Brand address: Fortify bond between academics, athletics. NCAA News. Retrieved from http://fs.ncaa.org/Docs/NCAANewsArchive/2004/Associationwide/brand $\% 2$ baddress $\% 2 \mathrm{~b} \% 2$ bfortify $\% 2$ bbond $\% 2$ bbetween $\% 2$ bacademics $\%$ 2bathletics\%2b-\%2b1-19-04.html

Brand, M. (2006, January 7). Brand charts course for collegiate model's next century. NCAA News. Retrieved from http://fs.ncaa.org/Docs/NCAANewsArchive/2006/Associationwide/brand $\% 2$ bcharts $\% 2$ bcourse $\% 2$ bfor $\% 2$ bcollegiate $\% 2$ bmodel_s $\% 2$ bnext $\% 2$ bcent ury $\% 2 \mathrm{~b}-\% 2 \mathrm{~b} 1-16-06 \% 2$ bncaa\%2bnews.html 
Brown, G. (2014, October 28). NCAA graduation rates: A quarter-century of tracking academic success. Retrieved from http://www.ncaa.org/about/resources/research/ncaagraduation-rates-quarter-century-tracking-academic-success?division=d3

Byers, W., \& Hammer, C. (1995). Unsportsmanlike conduct: Exploiting college athletes. Ann Arbor: The University of Michigan Press.

Clarke, P. (2013, March 21). NCAA tournament 2013: Breaking down the business behind March Madness. Bleacher Report: Sport Business. Retrieved from http://bleacherreport. com/articles/1575128-ncaa-tournament-2013-breaking-down-the-business-behindmarchmadness

Daly, A., \& Moloney, D. (2004). Managing corporate rebranding. Irish Marketing Review, $7(1 / 2), 30-36$.

Dowling, G. (1994). Corporate reputations. London: Kogan Page.

Gapp, R., \& Merrilees, B. (2006). Important factors to consider when using internal branding as a management strategy: A healthcare case study. Journal of Brand Management, 14(1/2), 162-176. doi:10.1057/palgrave.bm.2550058

Gramsci, A. (1971). In Q. Hoare \& G.N. Smith (Eds.), Selections from the prison notebooks. New York: International Publishers.

Gregory, J. (1991). Marketing corporate image. Lincolnwood, IL: NTC Business Books.

Greyser, S.A. (2009). Corporate brand reputation and brand crisis management. Management Decision, 47(4), 590-602. doi:10.1108/00251740910959431

Hall v. University of Minnesota, 530 F. Supp. 104 (D. Minn. 1982).

Hatch, M., \& Schultz, M. (2003). Bringing the corporation into corporate branding. European Journal of Marketing, 37(7/8), 1041-1064. doi:10.1108/03090560310477654

Herndon, M. (2014, July 10). NCAA president Mark Emmert challenged by Senate committee.al.com. Retrieved from http://www.al.com/sports/index.ssf/2014/07/ncaa_president_mark_emmert_cha.html

Hosick, M. (2014, October 28). Student-athletes earn diplomas at record rate: Graduation Success Rate jumps two points, virtually every demographic improves. News Articles. Retrieved from http://www.ncaa.org/about/resources/media-center/news/studentathletes-earn-diplomas-record-rate

Jacobson, S. (1992, October 8). Manley finally gets a read on education he missed. The Sun. Retrieved from http://articles.baltimoresun.com/1992-10-08/sports/1992282145_1_ dexter-reading-the-menu-ottawa-sun

Jenkins v. National Collegiate Athletic Association. No. 14-cv-02758-CW (2014).

LaForge, L., \& Hodge, J. (2011). NCAA academic performance metrics: Implications for institutional policy and practice. The Journal of Higher Education, 82(2), 217-235. doi:10.1353/jhe.2011.0008

Law v. National Collegiate Athletic Association, 134 F.3d 1010 (10th Cir. 1998).

McArdle, J.J., \& Hamagami, F. (1994). Logit and multilevel logit modeling of college graduation for 1984-1985 freshman student-athletes. Journal of the American Statistical Association, 89, 1107-1123. doi:10.1080/01621459.1994.10476849

McGuire, K. (2014, July 9). NCAA president being grilled by Senate committee. Collegefootballtalk.nbcsport.com. Retrieved from http://collegefootballtalk.nbcsports. com/2014/07/09/ncaa-president-being-grilled-by-senate-committee/

Merrilees, B., \& Miller, D. (2008). Principles of corporate rebranding. European Journal of Marketing, 42(5/6), 537-552. doi:10.1108/03090560810862499

National Collegiate Athletic Association. (1991, June). NCAA academic performance study: Report 91-01 - A description of college graduation rates for 1984 and 1985 freshman student-athletes. Overland Park, KS: NCAA.

National Collegiate Athletic Association. (1994, July). NCAA research report: Report 91-07 - Executive summary of reports 91-01 to 91-06. Overland Park, KS: NCAA.

National Collegiate Athletic Association. (2004, April). NCAA strategic plan: NCAA executive committee. Indianapolis, IN: NCAA 
National Collegiate Athletic Association. (2010a). Branding and communications major NCAA challenges from group perspective. President's Briefing Documents. Retrieved from http://fs.ncaa.org/Docs/newmedia/2010/Emmert/Part3/BC.html

National Collegiate Athletic Association. (2010b). Branding and communications group functional description. Retrieved from http://fs.ncaa.org/Docs/newmedia/2010/Emmert/ Part3/BC/BC1.html

National Collegiate Athletic Association. (2010c). Protecting the collegiate model. Retrieved from http://fs.ncaa.org/Docs/newmedia/2010/Emmert/Part5/protecting.html

National Collegiate Athletic Association. (n.d.). NCAA core values. Retrieved from http:// www.ncaa.org/about/ncaa-core-values

National Collegiate Athletic Association (2014a, July 9). NCAA president's testimony on value of college model: NCAA President Mark Emmert testified Wednesday about the value of college sports before the U.S. Senate Committee on Commerce, Science \& Transportation. Retrieved from http://www.ncaa.org/about/resources/media-center/ news/ncaa-president $\%$ E2\%80\%99s-testimony-value-college-model

National Collegiate Athletic Association. (2014b). Bylaw 2.9: The principle of amateurism. Legislative Services Database - LSDB $i$. Retrieved from https://web1.ncaa.org/LSDBi/ exec/bylawSearch

National Collegiate Athletic Association v. Board of Regents of Univ. of Oklahoma, et al., 468 U.S. 85 (1984).

National Collegiate Athletic Association v. Tarkanian, 488 U.S. 179 (1988).

Northwestern University and College Athletes Players Association (CAPA), Decision and Direction of Election. No. 13-RC-121359 (March 26, 2014).

Nyad, D. (1989, May 28). View of sport: How illiteracy makes athletes run. The New York Times. Retrieved from http://www.nytimes.com/1989/05/28/sports/views-of-sport-howilliteracy-makes-athletes-run.html?pagewanted=all\&src=pm

O’Bannon et al. v. NCAA et al., No. 09-3329, 2014 WL 3899815 (N.D. Cal. August 8, 2014).

Brief for National Collegiate Athletic Association as Appellant, O'Bannon et al. v. NCAA et al., Nos. 14-16601, 14-17068 (November 14, 2014).

Olins, W. (1978). The corporate personality: An inquiry into the nature of corporate identity. New York: Mayflower Books.

Ross v. Creighton University, 957 F.2d 410 ( $7^{\text {th }}$ Cir. 1992).

Sack, A.L., \& Staurowsky, E.J. (1998). College athletes for hire: The evolution and legacy of the NCAA amateur myth. Westport, CT: Praeger Press.

Schroeder, G. (2012, December 12). College football playoff revenue distribution set. USA Today. Retrieved from http://www.usatoday.com/story/sports/ncaaf/bowls/2012/12/11/ college-football-bcs-playoff-revenue-money-distribution-payouts/1762709/

Selingo, J. (2012, March 2). The rise and fall of the graduation rate. The Chronicle of Higher Education. Retrieved from http://chronicle.com/article/The-RiseFall-of-the/131036/

Solomon, J. (2014, November 15). NCAA relies heavily on Supreme Court case to appeal paying players. CBSSports.com. Retrieved from http://www.cbssports.com/collegefootball/writer/ jon-solomon/24810277/ncaa-relies-heavily-on-supreme-court-case-to-appeal-paying-players

Southall, R.M., Nagel, M.S., Amis, J., \& Southall, C. (2008). A method to March Madness: Institutional logics and the 2006 National Collegiate Athletic Association Division I men's basketball tournament. Journal of Sport Management, 22(6), 677-700.

Southall, R.M., \& Staurowsky, E.J. (2013). Cheering on the collegiate model: Creating, disseminating, and imbedding the NCAA's redefinition of amateurism. Journal of Sport and Social Issues, 37(4), 403-429. doi:10.1177/0193723513498606

Southall, R.M., \& Staurowsky, E.J. (2014, April 25). College sport reform or collegiate model re-branding? An analysis of CAP Act and other federal legislative proposals. $7^{\text {th }}$ Annual CSRI Conference on College Sport. Columbia, SC.

Stuart, H., \& Muzellec, L. (2004). Corporate makeovers: Can a hyena be rebranded? Journal of Brand Management, 11(6), 472-482. doi:10.1057/palgrave.bm.2540193 